\section{Quality control charts in the processing of soybean seeds}

\author{
Matheus André de Jesus ${ }^{1^{*}}$ (D) , Victor Marsel Amorim Reis ${ }^{1}$ (D) Fellipe Ramos \\ Sampaio ${ }^{1}$ (D) Francisco Leandro Posse ${ }^{2}$ (D) Rafael Marani Barbosa ${ }^{1}$
}

ABSTRACT: Soybean is a crop of great economic relevance in the world, with seed production being one of the most important sectors of its agro-industrial complex. Processing is one of the final stages of the seeds production process, it aims to remove impurities, select seeds by shape, size and density and pack properly. Monitoring and quality control at different stages of the process ensures that seeds meet storage and market standards. The aim of this study was to evaluate the different stages of processing in the physical and physiological performance of three cultivars of soybean seeds using statistical process control tools. The work was carried out at the seed processing unit with the cultivars M8644 IPRO, M8349 IPRO and M8808 IPRO, with sampling at eight points throughout the process. Water content, physical purity, germination, first count, accelerated aging, tetrazolium (vigor and viability), mechanical damage and electrical conductivity were evaluated. During the process, mean and amplitude control charts were used for each test. The use of control charts made it possible to monitor the process of soybean seed processing, pointing out the methodology as a tool to determine existing problems, to promote continuous improvement in the performance of seed processing.

Index terms: Glycine $\max$ (L.) Merrill, statistical process control, mechanical damage, physiological performance.

RESUMO: A soja é uma cultura de grande relevância econômica mundial, sendo a produção de sementes um dos setores mais importantes de seu complexo agroindustrial. O beneficiamento é uma das etapas finais do processo de produção das sementes, que visa remover as impurezas, selecionar as sementes por forma, tamanho e densidade e embalar de forma adequada. O monitoramento e o controle de qualidade nas diferentes etapas do processo garantem que as sementes atendam aos padrões de armazenamento e mercado. $\mathrm{O}$ objetivo deste estudo foi avaliar diferentes etapas do processamento no desempenho físico e fisiológico de três cultivares de sementes de soja utilizando ferramentas de controle estatístico de processo. $O$ trabalho foi realizado na unidade de beneficiamento de sementes com as cultivares M8644 IPRO, M8349 IPRO e M8808 IPRO, com amostragem em oito pontos ao longo do processo. Foram avaliados o teor de água, pureza física, germinação, primeira contagem, envelhecimento acelerado, tetrazólio (vigor e viabilidade), danos mecânicos e condutividade elétrica. Durante o processo, gráficos de controle de média e amplitude foram usados para cada teste. A utilização de cartas de controle possibilitou o acompanhamento do processo de beneficiamento de sementes de soja, apontando a metodologia como ferramenta para apuração dos problemas existentes, a fim de promover a melhoria contínua no desempenho do beneficiamento da semente.

Termos para indexação: Glycine max (L.) Merrill, controle estatístico de processo, dano mecânico, qualidade fisiológica.
Journal of Seed Science, v.43, e202143031, 2021

http://dx.doi.org/10.1590/ 2317-1545v43245104
*Corresponding author E-mail:majesus@uesc.br

Received: $10 / 29 / 2020$. Accepted: 8/25/2021.

\footnotetext{
${ }^{1}$ Universidade Estadual de Santa Cruz, Campus Soane Nazaré de Andrade, Rodovia Jorge Amado, Km 16, Bairro Salobrinho, 45662-900. Ilhéus, Bahia, Brasil.
}

\footnotetext{
${ }^{2}$ Universidade Estadual de Goiás, Av. Sra. de Santana, N 598, Bairro Santa Luzia, 73900-000, Posse, Goiás, Brasil.
} 


\section{INTRODUCTION}

The production of high-quality soybean seeds involves the adoption of technology and adequate management in all stages. The choice of cultivars with high productivity potential is important to guarantee an adequate stand and uniformity of plants. These characteristics, associated with seed vigor, measured by high germination, and uniform seedling emergence in less time, under adverse conditions (Ebone et al., 2019) guarantee the success of the agroindustrial enterprise.

The maximum physiological potential of the seed is collected in the field, but the harvest and post-harvest processes can contribute to the reduction of its performance. In the search for high seed quality, processing is essential, as it removes the inert fraction from the lot, and classifies it by size, shape and density. This process improves these characteristics using homogenization and contribution with the improvement of the physical and physiological quality of the seed (Kirchner et al., 2014; Conrad et al., 2017; Amaral et al., 2018).

By definition, "quality" is the inverse of variability, that is, the smaller the variation among samples of the same product, or the greater the conformity of that product with a parameter established as a standard, the higher its quality in the production line (Montgomery, 2009). During seed processing, the objective is quality and standardization. Therefore, the seeds are submitted from receipt to packaging and distribution. The processing was linked to the improvement of the quality of peanut seed lots (Barbosa et al., 2014), corn (Nerling et al., 2014), mombaça grass (Melo et al., 2016), soybean (Amaral et al., 2018) and kidney beans (Mertz et al., 2007).

On the Seed Processing Unit (SPU), the seed lot goes through several stages, and during the processing, the seed is subject to common and special causes of variation. Common causes of variation are intrinsic to the process with constant occurrence, whereas special causes of variation are sporadic and unpredictable. Both cause damage to the process, reflecting on the reduction of the physiological quality of the seeds, therefore, they must be quickly identified and eliminated or minimized (Ishikawa, 1990; Alves and Samohyl, 2005).

The soybean seed is highly susceptible to mechanical damage, since the vital parts of the embryonic axis are located under thin tegument. During processing, damage can be caused by falls, impacts with rigid surfaces, unregulated equipment, improper seed moisture level, among others. These problems can be reduced or even avoided with good management. The detection of these points and their causes is the key to preserving the quality of the seeds during the process (Conrad et al., 2017; Amaral et al., 2018).

Widely used in quality control programs in the industry, Statistical Process Control (SPC), through control chart graphics, allows the identification of common and special causes of variation within the production process (Montgomery, 2009). In agribusiness, its use is not yet common, but the efficiency of SPC has already been proven in mechanized processes in cotton (Silva et al., 2007), tomato (Voltarelli et al., 2015), in the application of pesticides crops in coffee (Silva et al., 2016), peanut sowing (Zerbato et al., 2017) and monitoring of soybean seed quality (Alcântara et al., 2018).

In view of its use and applicability in different areas, it was hypothesized that SPC can contribute to programs for continuous improvement and quality control of soybean seeds within the SPU. Therefore, the aim of this study was to evaluate the different stages of processing in the physical and physiological seed performance of three soybean cultivars using statistical process control.

\section{MATERIAL AND METHODS}

The work was carried out at CIASEEDS Seed Processing Unit (SPU), located on the Serrana farm - BR 020, km

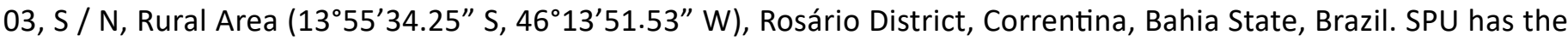
capacity to benefit 25 thousand bags of soybean seeds per day. It has mug-type elevators with heights between 6 and $12 \mathrm{~m}$, conveyors, and pipes for transporting seeds during processing. 
Seeds of three soybean cultivars, M8644 IPRO, M8349 IPRO and M8808 IPRO, produced in the 2018/2019 harvest season, were evaluated. Sampling was carried out in the following stages of seed processing: (1) reception; (2) pre-cleaning; (3) cleanliness; (4) selection by shape (except the M8644 IPRO cultivar, due to its oblong shape); (5) standardization by size - $5.5 \mathrm{~mm}$ sieve; (6) density selection ( $5.5 \mathrm{~mm}$ ); (7) cooling; and (8) bagging (5.5 mm) (Figure 1).

During seed processing, five $1 \mathrm{~kg}$ subsamples were collected at each stage, to form a sample composed of the same weight and its duplicate, packed in a paper bag (Brasil, 2009). The samples were taken to the CIASEEDS Seed Quality Control Laboratory and to the Phytotechnics Laboratory of the State Universities of Santa Cruz, located in Ilhéus $\left(14^{\circ} 47^{\prime} 52^{\prime \prime}\right.$ S, $39^{\circ} 10^{\prime} 22^{\prime \prime}$ W), Bahia State, Brazil, where the evaluations were carried out:

\section{Water Content}

For each sample, two subsamples of 25 seeds were used and the determination was carried out by the heater method at a temperature of $105 \pm 3{ }^{\circ} \mathrm{C}$ for 24 hours (Brasil, 2009). The results were expressed as a percentage (wet basis).

\section{Mechanical damage}

It was determined by the sodium hypochlorite test (Krzyzanowski et al., 2004), with four subsamples of 50 seeds, which were immersed in $\mathbf{0 . 1 3 \%}$ sodium hypochlorite solution for 10 minutes. After this period, the seeds were dried on paper towels and evaluated by computing the number of seeds soaked, with the results expressed as a percentage.

\section{Purity}

From each sample point, a working sample of approximately $500 \mathrm{~g}$ was taken, which was separated into three components: pure seeds, other seeds and inert material. The results were expressed as a percentage by weight of the working sample (Brasil, 2009), considering only the fraction of pure seeds.

\section{Germination and First Count}

The germination test was performed with four subsamples of 50 seeds per sample. These were distributed on sheets of paper for germination moistened with distilled water equivalent to 2.5 times the mass of the dry substrate, using two leaves under the seeds and another covering them, to form the rolls, which were kept in a germination chamber at $25{ }^{\circ} \mathrm{C}$ for eight days. The first and final counts were performed on the $5^{\text {th }}$ and $8^{\text {th }}$ days, respectively. The values were obtained in percentage of first count and germination (Brasil, 2009).

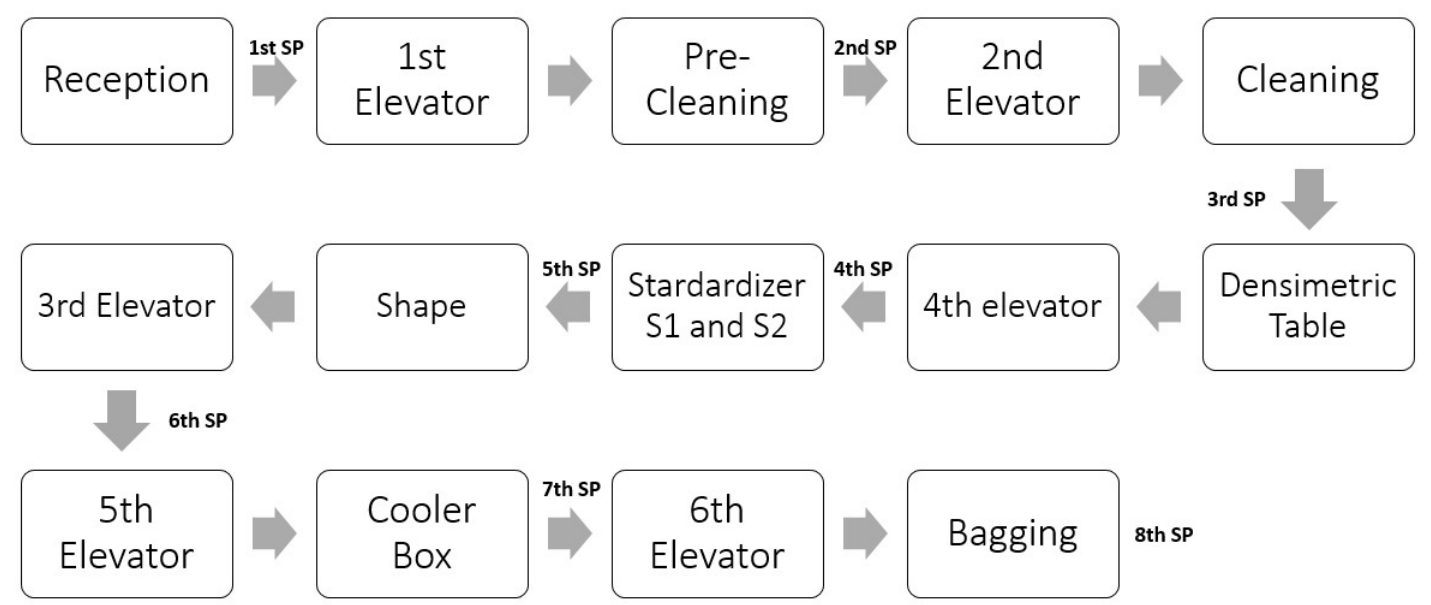

Figure 1. Flowchart of the stages of the processing of soybean seeds and the Sampling Points (PA) in the Seed Processing Unit of the company CIASEEDS in Correntina, BA. 


\section{Accelerated Aging}

Approximately 250 seeds, as they were placed in a single layer on a steel screen $2 \mathrm{~cm}$ from the bottom of plastic boxes, containing $40 \mathrm{~mL}$ of distilled water. The boxes were covered, placed in a biochemical oxygen demand (BOD) oven at $41^{\circ} \mathrm{C}$ for 48 hours and after that period the seeds were submitted to germination tests, with the counting performed on the fifth day (Marcos-Filho, 2020).

\section{Tetrazolium test}

100 seeds were used, two subamples, and placed to soak in germination paper moistened with 2.5 times their weight in distilled water for 16 hours, then they were allocated in B.O.D. at $25^{\circ} \mathrm{C}$. After that period, the seeds were submerged in a solution of 2, 3, 5-triphenyl-tetrazolium chloride at $0.075 \%$, at $41^{\circ} \mathrm{C}$ for two hours, in the dark. The seeds were evaluated, and classified according to their vigor potential (1-3) and viability (1-5) (França-Neto and Krzyzanowski, 2018).

\section{Electrical Conductivity}

Four subsamples of 50 seeds, were weighed and placed to soak in $75 \mathrm{~mL}$ of deionized water at $25{ }^{\circ} \mathrm{C}$, for 24 hours, in plastic cups with a capacity of $200 \mathrm{~mL}$. After this period, the electrical conductivity of the solution was measured in a digital conductivity meter, and the results, expressed in $\mu \mathrm{S} \cdot \mathrm{cm}^{-1} \cdot \mathrm{g}^{-1}$ (Vieira and Marcos-Filho, 2020).

\section{Statistical procedures}

The X-Bar R control charts were used to monitor the process, using medium and amplitude variables. The control limits are lower (LLC) and upper (ULC), whose central line is the general average $(\bar{x})$. The control limits indicate whether there is variation in the results due to uncontrolled causes in the process (common or special), and are calculated based on the standard deviation of the variables (Equation 1) (Montgomery, 2009):

$$
\begin{aligned}
& U L C=\bar{x}+3 . \sigma \\
& L L C=\bar{x}+3 . \sigma
\end{aligned}
$$

Equation 1. Calculation of upper and lower control limits.

Legend: ULC: upper control limit; LLC: lower control limit; $\bar{x}$ : general mean of the variable; $\sigma$ : standard deviation.

All analyzes and graphs were generated by the Minitab ${ }^{\circ}$ software (Minitab, 2019).

\section{RESULTS AND DISCUSSION}

The sources of common causes of variation in a process, were organized and identified in this work as 6 M's, with a fishbone diagram (Figure 2), which is a graphic tool to analyze the main influencing factors (causes) on a certain problem (effect) (Ishikawa, 1990).

The water content of the seeds varied from 10.9 to $12.8 \%$, with a progressive reduction during processing for all cultivars. The lowest values were obtained after the cooling and bagging steps. The reduction of the water content of the seeds during the processing benefits the maintenance of the physiological quality and the storage of the seeds (Demito and Afonso, 2009).

The seed lots showed high physical and physiological quality since the reception, and the seeds reached greater purity, germination and vigor throughout the process, since the values increased with each stage. One of the premises of the beneficiation is to remove impurities and damaged or non-standard seeds, raising the quality to the final product (Lopes et al., 2011; Kirchner et al., 2014; Moreano et al., 2018). 


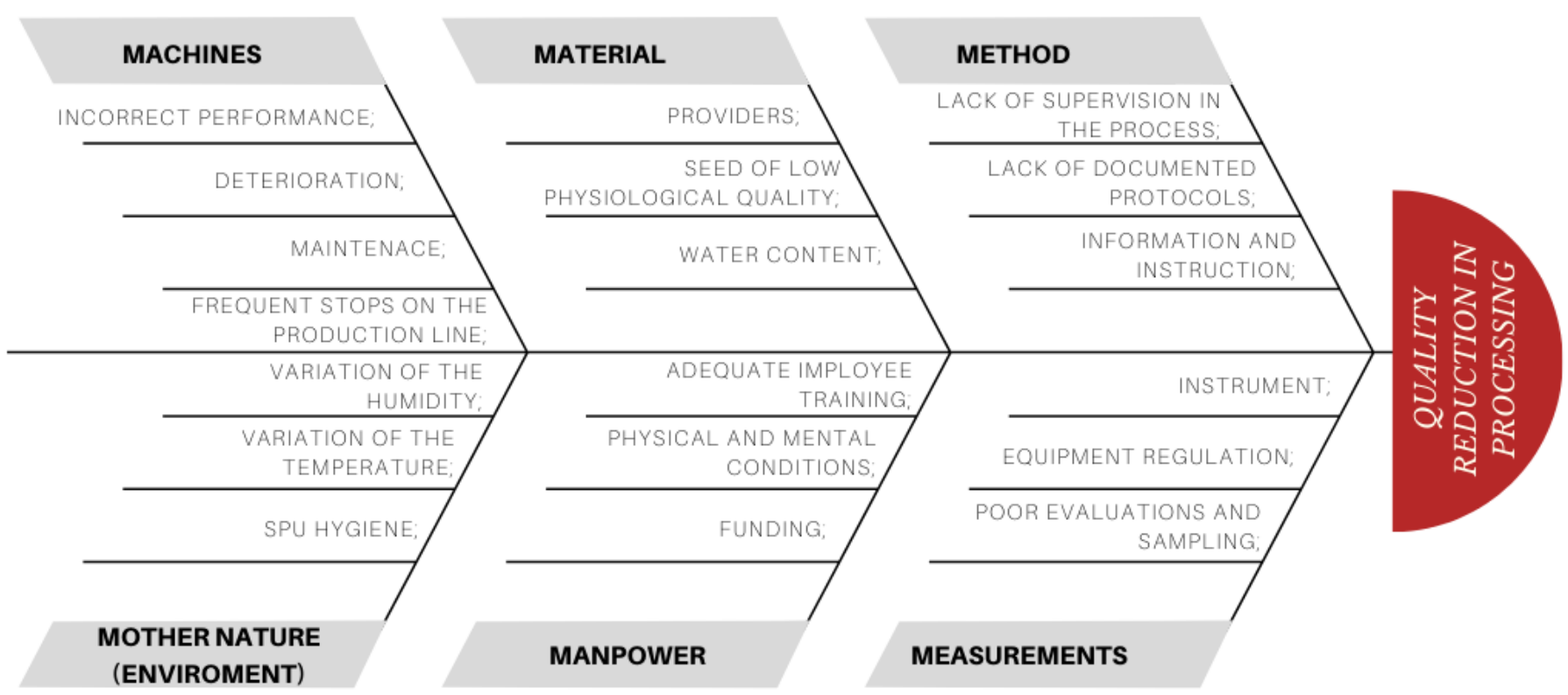

Figure 2. Diagram of Cause and Effect (6 M's) of the processing of soybean seeds. Source: Research data.

In control charts, upper control limits (ULC) and lower control limits (LLC) are established to help judge the significance of the variation in product quality. When analyzing a control chart, if a point is beyond the ULC or LLC, the process will be characterized as out of control. In addition to this rule there are additional rules that are used to check whether a process is under control or not. An out-of-control process is undergoing variations due to some intrinsic (6 M's) uncontrolled or special cause. Causes of special variations are of external origin and can occur due to accidents or unexpected problems during the process, machinery breakdown, mixing of materials, reduction or unexpected drop in flow, among others.

For mechanical damage, all processes were found out of control. The points beyond the control limits occurred mainly for the 'M8644' (Figure 3), which at reception was already above the ULC, followed by a large reduction in values, with points below the LLC in cleaning and separation by density, showing the high efficiency in subsequent steps of the process. For 'M8349' and 'M8808', a single point was out of range, in the cleaning and pre-cleaning stage, respectively (Figures 4 and 5). These variations occurred due to the low amplitude of the data, which varied from 2 to $10 \%$ of damaged seeds, thus being within the standards for commercialization (Kryzanowski et al., 2004). Moreover, although the soybean seed is susceptible to mechanical damage, resulting from harvesting, drying (Maryam and Oskouie, 2011) during the processing, there was a reduction and control of the damage levels. This indicates a process under control, with little influence from the $6 \mathrm{M}$ 's, classifying the process as suitable for this variable, mainly for the 'M8808' which showed a reduction in values during the process.

In the control charts for purity, there was little variation due to the high quality of the harvest, which made the seed lots already present high purity from the moment of reception, and the data amplitude was close to zero (Figures 3, 4 and 5). In the control charts for averages, the closer the data gets to the center line, the more stable the process is. For all cultivars, the LLC and ULC overlapped the average line, as their values were equal to the average. The control charts for purity, present ideal amplitude, configuring a perfect process where there is no variation between the points, obtaining in the concept of homogeneity, maximum quality.

In the first count, which is an observation made during the development of the radicle emergence and indicates the percentage of normal seedlings (Matthews et al., 2018), the processing for 'M8349' and 'M8808' was considered under control (Figures 4 and 5), that is, they are efficient in reaching the objective of the process, maintaining the high capacity of the seed to germinate and establish quickly. 

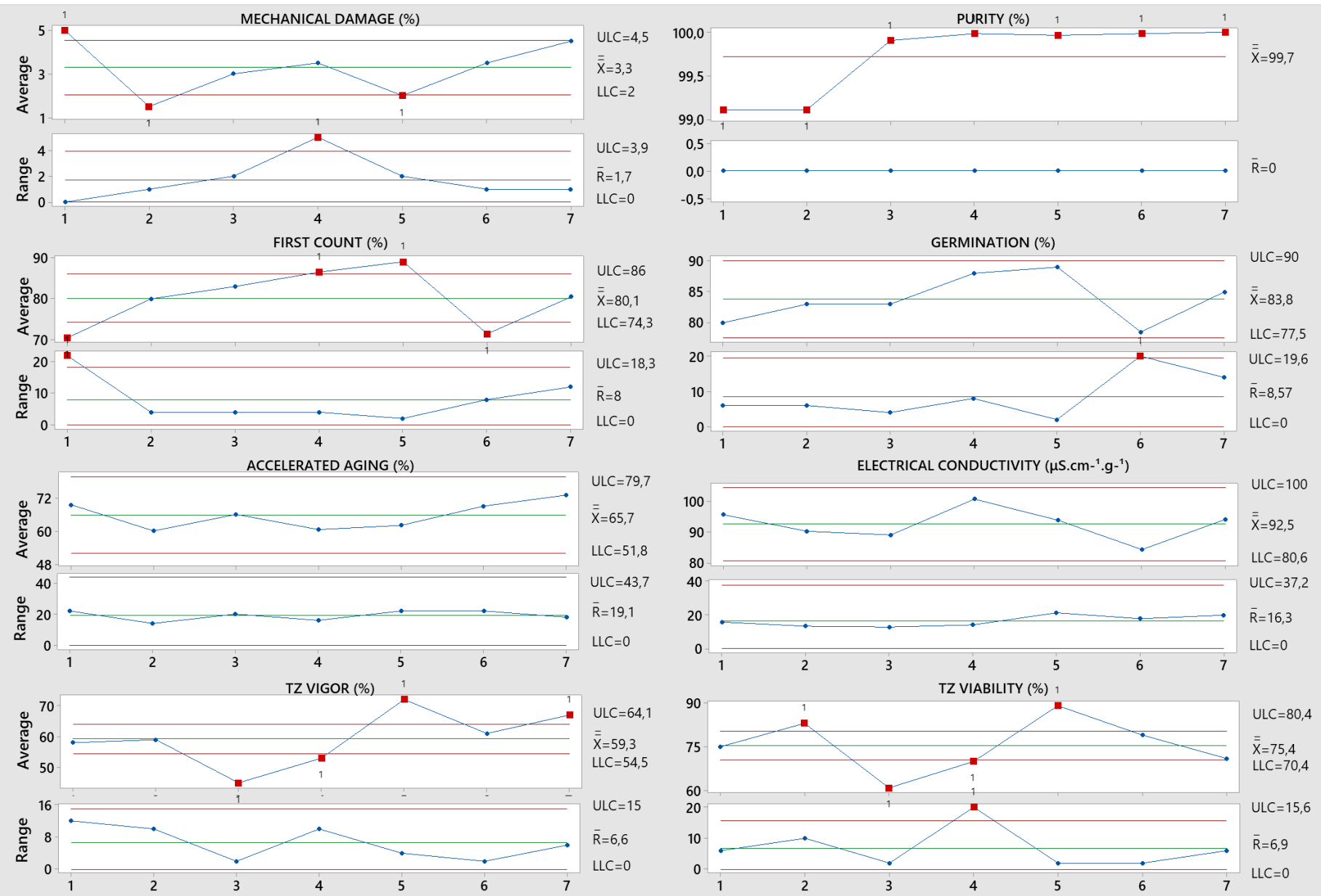

Source: Research data. Legend: 1 - reception; 2 - pre-cleaning; 3 - cleaning; 4 - standardization by size; 5 - density selection; 6 - cooling, and 7 - bagging.

Figure 3. Control charts of the variables analyzed for the cultivar M8644 IPRO according to the different stages of processing.

The control charts for the first count show greater variation in the processing of the 'M8644' (Figure 3), with points below the LLC during reception and cooling, and points above the ULC in standardization by size and selection by density. The point below the LLC at the reception, indicates low quality of the raw material in comparison to the other cultivars. The points above the ULC indicate that the initial stages of processing already contribute a lot to the physiological quality, because even with the low initial quality, at these points, the 'M8644' reaches the standards of the other cultivars. The cooling point below the LLC, on the other hand, may be due to the causes of variation 'Measurement', by sampling, or 'Environment', due to the drastic reduction in temperature of the seeds.

The germination values in all stages remained high and stable. For this variable, the processes were considered apt, that is, all points were within the control limits, except for one point beyond the limits in the amplitude chart for 'M8644', which shows the occurrence of a high variability, but without impairing the efficiency of the process (Figures 3, 4 and 5). The initial high quality of the seeds, evidenced by the purity and germination test, meant that the cause of variation 'Raw Material' presented in the cause and effect diagram was minimized.

In accelerated aging, the cards for 'M8644' and 'M8808' (Figures 4 and 5) are under control. The 'M8349' showed greater amplitude, and in the averages chart there is one point above the ULC for cleaning and one below the LLC for density separation. However, the cultivars 'M8808' and 'M8349' were within the standards that characterize vigorous seeds in this test, with averages above $80 \%$ (Marcos-Filho, 2020). Despite being under control, 'M8644' showed 
lower levels of vigor than other cultivars. Therefore, a good evaluation by the control chart does not necessarily mean that this lot is vigorous or recommended for storage, since it does not meet the need for seeds with high physiological performance.

The control charts for electrical conductivity indicated that for ' $\mathrm{M} 8808$ ', the process started above the upper control limit, with a value far from the process average (Figure 5). However, the point located in the region of $55.3 \mu \mathrm{S} . \mathrm{cm}^{-1} \cdot \mathrm{g}^{-1}$, was classified with very high vigor (Prado et al., 2019), a fact that is associated with high quality raw material. As for the cleaning step, with points below the lower control limit, in this case the point outside the control limit, which also does not represent a quality problem, since it is the proximity to the high-quality extremes that is desired for the beneficiation process.

Vigor oscillating between medium and high $\left(110\right.$ to $\left.71 \mu \mathrm{S} . \mathrm{cm}^{-1} \cdot \mathrm{g}^{-1}\right)$ was indicated by the electrical conductivity test for 'M8644 IPRO' seeds (Prado et al., 2019). The process is under control, but with lower averages when compared to other cultivars. What may have happened due to the lower performance of the 'M8644' since reception, indicating the influence of some of the 6 M's, not only 'Raw Material', but 'Machines' and 'Methods'. This cultivar is not separated by form, and thus, its quality may be impaired, which leads to the need for adjustments in the process.

In the vigor and viability of seeds evaluated by the tetrazolium test, 'M8644' showed the lowest averages. High values were obtained for the other cultivars, especially 'M8808', which reached viability above $90 \%$ in all sampled

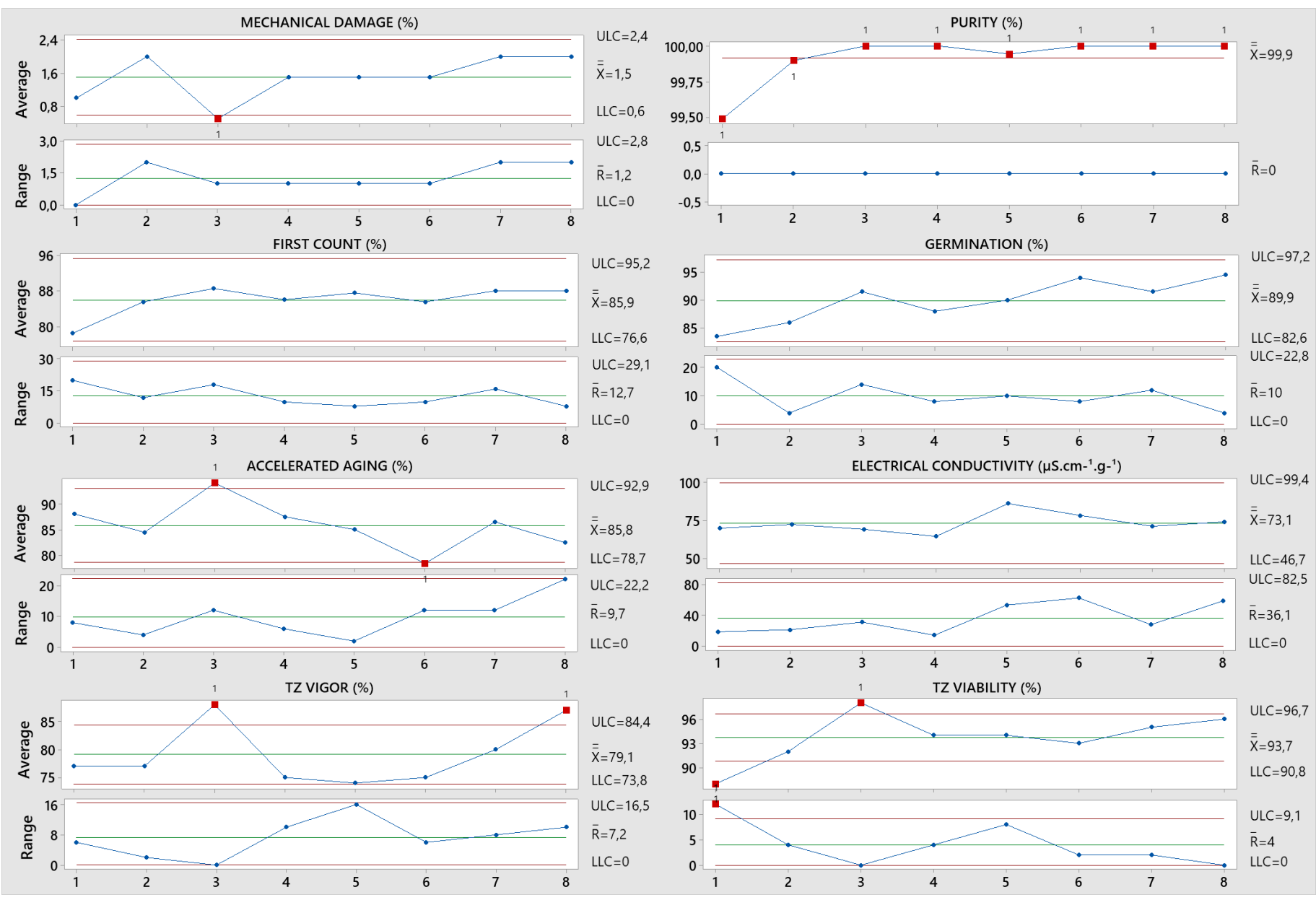

Source: Research data. Legend: 1 - reception; 2 - pre-cleaning; 3 - cleaning; 4 - standardization by shape; 5 - standardization by size; 6 - density selection; 7 - cooling, and 8 - bagging.

Figure 4. Control charts of the variables analyzed for the cultivar M8349 IPRO according to the different stages of processing. 


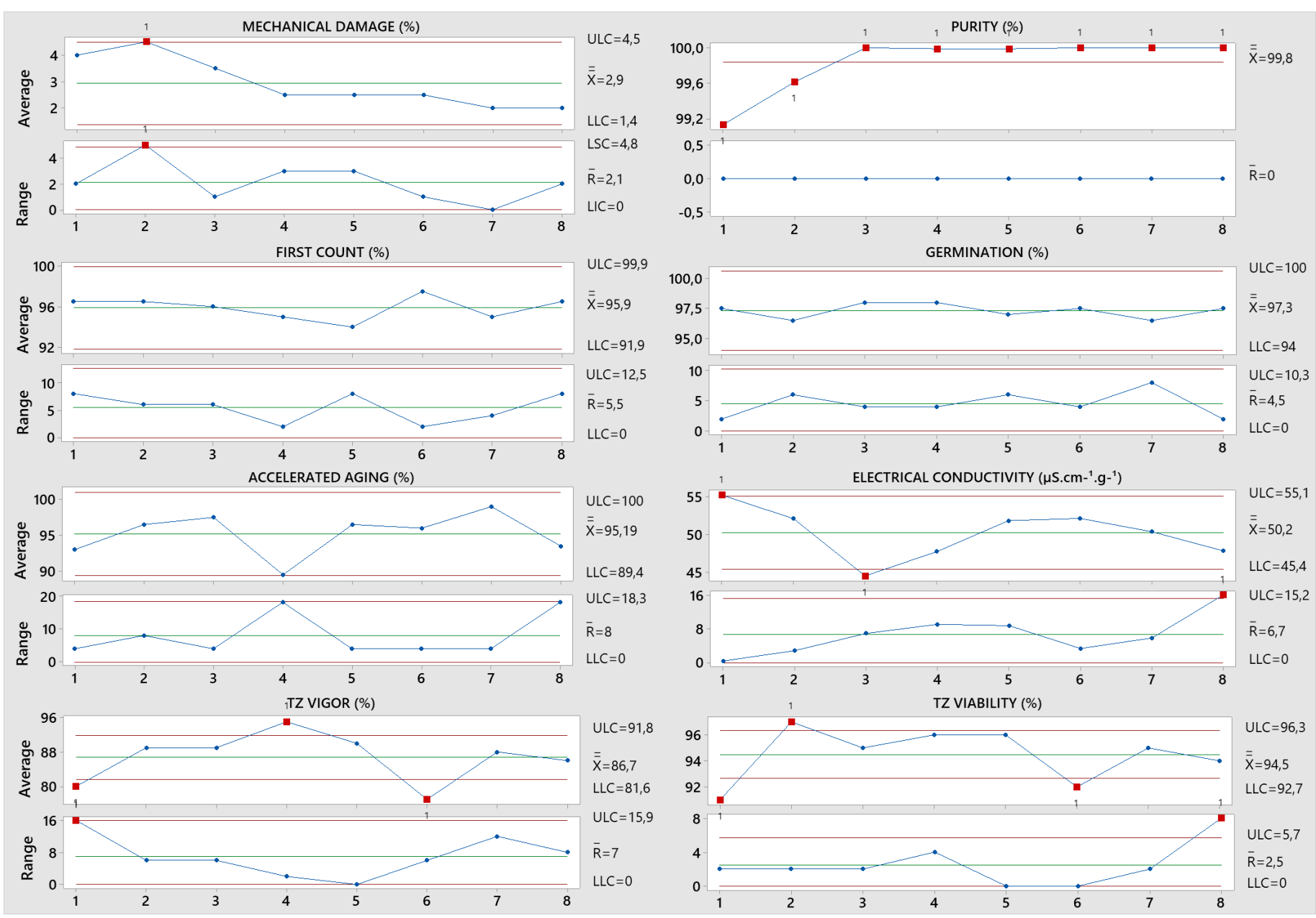

Source: Research data. Legend: 1 - reception; 2 - pre-cleaning; 3 - cleaning; 4 - standardization by shape; 5 - standardization by size; 6 - density selection; 7 - cooling, and 8 - bagging.

Figure 5 Control charts of the variables analyzed for the cultivar M8808 IPRO according to the different stages of processing.

stages. However, the control charts for the two variables identified out-of-control processes, which does not necessarily reflect low performance, as some points were obtained above the ULC (Figures 3, 4 and 5).

In the 'M8644' charts there was a similar behavior for vigor and viability and the cleaning and standardization steps by size showed points below the LLC, but then there was a significant improvement. In the selection by density for the two variables, and for the bagging in force, the points were found above the ULC. The stage of selection by density is characterized as an important operation to increase seed lot performance (Ferreira and Sá, 2010), and at this point the cultivar obtained values above the control levels, which indicates the efficiency of the process, despite the quality of the raw material, when compared to the others.

The 'M8349' showed points above the ULC in bagging for vigor, and in cleaning for the two variables, in addition to a point below the LLC on receipt in the letter of viability. In the 'M8808' there were points below the LLC for reception and selection by density, and above the ULC in the selection by form for vigor and pre-cleaning for viability. In this case, the out-of-control charts do not indicate an ineffective process, but on the contrary, they show that despite the great variability in the samples, the process is being effective in improving the vigor and viability characteristics of the seed lots for all cultivars evaluated. This behavior is due to the qualitative and thorough nature of the results obtained with the tetrazolium test, which has great variability. Applying attribute control cards may be an option in this case. 
Therefore, the application of Statistical Process Control in the processing of soybean seeds is feasible and effective to classify the process as fit or not, based on physical and physiological attributes. However, one must consider the variable that will be used in this classification, and all the factors that may influence the variability in the process, through the cause-and-effect diagram, because as evidenced in this work, different raw materials require methods, machines, labor specific work, measurements and environment.

Thus, when applying this methodology within the routine of the SPU, it is possible to continuously monitor the process and to quickly identify the points that cause the most variation within this process, and to enable quick and effective action for its resolution.

\section{CONCLUSIONS}

Statistical Process Control by control charts during beneficiation made it possible to monitor the physical and physiological performance of soybean seeds, regardless of the cultivar used, pointing out the methodology as a tool to identify potential problems, in order to promote continuous improvement in performance of the Seed Processing Unit and ensure high quality seeds at the end of the process.

\section{ACKNOWLEDGEMENTS}

To the Coordenação de Aperfeiçoamento de Pessoal de Nível Superior - Brasil (CAPES) - for the study financed in part by the Finance Code 001. To the Research Support Foundation of the State of Bahia - FAPESB (№ BOL0466/2019), for the concession of a grant, to the State University of Santa Cruz (UESC), and to CiaSeeds Agricola LTDA., for the research supporting.

\section{REFERENCES}

ALCÂNTARA, A.S.; PRADO, J.P.; CORRÊA, R.G.; SILVA, R.P.; VOLTARELLI, M.A.; VIEIRA, R.D. Quality monitoring of soybean seed tests using Statistical Process Control. Revista Brasileira de Engenharia Agrícola e Ambiental, v.22, n.10, p.689-695, 2018. https://www. scielo.br/scielo.php?script=sci_arttext\&pid=S1415-43662018001000689.

ALVES, C.C.; SAMOHYL, R. W. O monitoramento de processos industriais via gráficos de controle CUSUM. Revista UNIVILLE, v.10, p.72-80, 2005. http://www.abepro.org.br/biblioteca/enegep2011_tn_sto_136_863_18856.pdf.

AMARAL, D.R.; DOBIS, F.S.; CARVALHO, T.C. Avaliação da qualidade física e fisiológica de sementes de soja durante o beneficiamento. Pesquisa Aplicada \& Agrotecnologia, v.11, n.2, p.43-52, 2018. https://revistas.unicentro.br/index.php/repaa/ article/download/5262/3710.

BARBOSA, R.M.; VIEIRA, B.G.T.L.; MARTINS, C.C.; VIEIRA, R.D. Qualidade fisiológica e sanitária de sementes de amendoim durante o processo de produção. Pesquisa Agropecuária Brasileira, v.49, n.12, p.977-985, 2014. https://www.scielo.br/scielo.php?pid=S0100204X2014001200977\&script=sci_abstract\&tIng=pt.

BRASIL. Ministério da Agricultura, Pecuária e Abastecimento. Regras para análise de sementes. Ministério da Agricultura, Pecuária e Abastecimento. Secretaria de Defesa Agropecuária. Brasília: MAPA/ACS, 2009. 399p. https://www.gov.br/agricultura/pt-br/ assuntos/insumos-agropecuarios/arquivos-publicacoes-insumos/2946_regras_analise_sementes.pdf

CONRAD, V.A.D.; RADKE, A.K.; VILLELA, F.A. Atributos físicos e fisiológicos em sementes de soja no beneficiamento. Magistra, v.29, n.2, p.56-63, 2017. https://magistraonline.ufrb.edu.br/index.php/magistra/article/view/421.

DEMITO, A.; AFONSO, A.D.L. Qualidade das sementes de soja resfriadas artificialmente. Engenharia na Agricultura, v.17 n.1, p.7-14, 2009. https://periodicos.ufv.br/reveng/article/view/79.

EBONE, L.A.; CAVERZAN, A.; CHAVARRIA, G. Physiologic alterations in orthodox seeds due to deterioration processes. Plant Physiology and Biochemistry, v.145, p.34-42, 2019. https://www.sciencedirect.com/science/article/abs/pii/S0981942819304292. 
FERREIRA, R.L.; SÁ, M.E. Contribuição de etapas do beneficiamento na qualidade fisiológica de sementes de dois híbridos de milho. Revista Brasileira de Sementes, v.32, n.4, p.99-110, 2010. https://www.scielo.br/pdf/rbs/v32n4/11.pdf.

FRANÇA-NETO, J.B.; KRZYZANOWSKI, F.C. Metodologia do teste de tetrazólio em sementes de soja. Londrina: Embrapa Soja, 2018. 108p. (Documentos/ Embrapa Soja, n.406).

ISHIKAWA, K. Introduction to quality control. Tradução de John H. Loftus. 3. ed. Tokyo: 3A Corporation, 1990. 435p.

KIRCHNER, J.H; MATTIONI, N.M.; ROBAINA, A.D.; PEITER, M.X.; BARZOTTO, F.; MEZZOMO, W. Qualidade física, fisiológica e danos mecânicos nas etapas do beneficiamento de sementes de soja. Revista Tecnologia e Ciência Agropecuária, v.8, n.2, p.15-20, 2014. https://revistatca.pb.gov.br/edicoes/volume-08-2014/volume-8-numero-2-junho-2014/tca8210.pdf.

KRZYZANOWSKI, F.C.; FRANÇA-NETO, J.B.; COSTA, N.P. Teste do hipoclorito de sódio para semente de soja. Londrina: Embrapa. 2004. 4p. (Circular Técnica, 37).

LOPES, M.M.; PRADO, M.O.D.; SADER, R.; BARBOSA, R.M. Efeitos dos danos mecânicos e fisiológicos na colheita e beneficiamento de sementes de soja. Bioscience Journal, v.27, n.2, p.230-238, 2011. http://www.seer.ufu.br/index.php/biosciencejournal/article/ view/7123.

MARCOS-FILHO, J. Teste de envelhecimento acelerado. In: KRZYZANOWSKI, F. C., VIEIRA, R. D., FRANÇA-NETO, J. B.; MARCOS-FILHO, J. (Ed.). Vigor de Sementes: conceitos e testes. Londrina: ABRATES, Cap.4, p.185-243, 2020.

MARYAM, D.; OSKOUIE, B. Study the effect of mechanical damage at processing on soybean seed germination and vigor. Journal of Agricultural and Biological Science, v.6, p.60-64, 2011. http://www.arpnjournals.com/jabs/research_papers/rp_2011/ jabs_0711_294.pdf.

MATTHEWS, S.; WAGNER, M.; KERR, L.; POWELL, A.A. Potential for early counts of radicle emergence and leakage of electrolytes as quick tests to predict the percentage of normal seedlings. Seed Science and Technology, v.46, n.1, p.1-18, 2018. https://www. ingentaconnect.com/contentone/ista/sst/2018/00000046/00000001/art00001?crawler=true\&mimetype=application/pdf.

MELO, L.F.; MARTINS, C.C.; SILVA, G.Z; BONETI, J.E.B.; VIEIRA, R.D. Beneficiamento na qualidade física e fisiológica de sementes de capim-mombaça. Revista Ciência Agronômica, v.47, n.4, p.667-674, 2016. http://ccarevista.ufc.br/seer/index.php/ccarevista/ article/view/4580.

MERTZ, L.M.; HENNING, F.A.; MAIA, M.S.; MENEGHELLO, G.E.; HENRIQUES, A.; MADAIL, R. Qualidade fisiológica de sementes de feijão-miúdo beneficiadas em mesa gravitacional. Revista Brasileira de Sementes, v.29, n.3, p.1-16, 2007. https://www.scielo.br/ scielo.php?pid=S0101-31222007000300001\&script=sci_abstract\&tlng=pt.

MONTGOMERY, D.C. Control charts for variables. In: MONTGOMERY, D.C. (Ed.) Introduction to statistical quality control. Arizona: Wiley. 2009. v.6, p.226-268.

MOREANO, T.B.; MARQUES, O.J.; BRACCINI, A.L.; SCAPIM, C.A.; FRANÇA-NETO, J.B.; KRZYZANOWSKI, F.C. Evolution of the physical and physiological quality of soybean seeds during processing. Journal of Seed Science, v.40, n.3, p.313-322, 2018. https://www. scielo.br/scielo.php?script=sci_abstract $\&$ pid=S2317-15372018000300313\&lng=en\&nrm=iso

NERLING, D.; COELHO, C.M.M.; MAZURKIÉVICZ, J.; NODARI, R.O. Qualidade física e fisiológica de sementes de milho durante o beneficiamento. Revista de Ciências Agroveterinárias, v.13, n.3, p.238-246, 2014. https://core.ac.uk/download/pdf/234148952.pdf.

PRADO, J.P.; KRYZANOWSKI, F.C.; MARTINS, C.C.; VIEIRA, R.D. Physiological potential of soybean seeds and its relationship to electrical conductivity. Journal of Seed Science, v.41, n.4, p.407-415, 2019. https://doi.org/10.1590/2317-1545v41n4214988

SILVA, R.P.; SOUZA, F.G.; CORTEZ, J.W.; FURLANI, C.E.A.; VIGNA, G.P. Variabilidade espacial e controle estatístico do processo de perdas na colheita mecanizada do algodoeiro. Engenharia Agrícola, v.27, n.3, p.742-752, 2007. https://www.scielo.br/scielo. php?script=sci_arttext\&pid=S0100-69162007000400018\&lang=pt.

SILVA, J.E.R.; CUNHA, J.P.A.R.; NOMELINI, Q.S.S. Controle estatístico de processo em pulverização hidropneumática na cultura do café. Coffee Science, v.11, n.1, p.11-21, 2016. http://www.sbicafe.ufv.br/handle/123456789/8168.

VIEIRA, R. D.; MARCOS-FILHO, J.; Teste de condutividade elétrica. In: KRZYZANOWSKI, F. C., VIEIRA, R. D., FRANÇA-NETO, J. B.; MARCOS-FILHO, J. (Ed.). Vigor de Sementes: conceitos e testes. Londrina: ABRATES, Cap.8, p.333-388, 2020.

VOLTARELLI, M.A.; SILVA, R.P.; ZERBATO, C.; SILVA, V.F.A.; PAIXÃO, C.S.S. Monitoramento das perdas no processo de colheita mecanizada de tomate industrial. Revista Engenharia na Agricultura - REVENG, v.23, n.4, p.315-325, 2015. https://periodicos.ufv. $\mathrm{br} / \mathrm{reveng} / \mathrm{article} / \mathrm{view} / 484$. 
ZERBATO, C.; FURLANI, C.E.A.; ORMOND, A.T.S.; GÍRIO, L.A.S.; CARNEIRO, F.M.; SILVA, R.P. Statistical process control applied to mechanized peanut sowing as a function of soil texture. PLOS ONE, v.12, n.7, e0180399, 2017. https://doi.org/10.1371/journal. pone.0180399 